\title{
PERINATAL OUTCOME IN ECLAMPSIA- A RETROSPECTIVE STUDY IN A TERTIARY CARE CENTRE
}

\author{
Priyali Purandare ${ }^{1}$, Sunita Mishra², Ratna Thakur ${ }^{3}$, Shruti Tiwari ${ }^{4}$
}

${ }^{1}$ Assistant Professor, Department of Obstetrics and Gynaecology, SAMC and PGI, Indore.

${ }^{2}$ Assistant Professor, Department of Obstetrics and Gynaecology, SAMC and PGI, Indore.

3 Professor, Department of Obstetrics and Gynaecology, SAMC and PGI, Indore.

${ }^{4}$ Resident, Department of Obstetrics and Gynaecology, SAMC and PGI, Indore.

ABSTRACT
BACKGROUND
Eclampsia is a life-threatening disease that is associated with a high maternal and perinatal mortality rate. Incidence of eclampsia
in India is high and it has remained high over the last few decades. The perinatal mortality associated with eclampsia too continues
to be high as compared to the developed nations.
Aims- To study the perinatal mortality in eclampsia in our institute and to analyse the risk factors associated with a poor perinatal
outcome.

\section{MATERIALS AND METHODS}

This is a retrospective observational study carried out in the Department of Obstetrics and Gynaecology at a Medical College Hospital from $1^{\text {st }}$ January 2015 to $31^{\text {st }}$ December 2015. The records of all patients with eclampsia were collected and the data was analysed using percentages.

\section{RESULTS}

The perinatal mortality in eclampsia was 33.8\%. Majority of eclamptics were primigravida (62.2\%). Perinatal mortality was high $(70.8 \%)$ when gestational age was less than 34 weeks and in babies weighing less than $2 \mathrm{~kg}(95.4 \%)$. Perinatal mortality was high when urine albumin was more than $2+$ and serum uric acid was more than $6 \mathrm{mEq} / \mathrm{lit}$. Perinatal mortality was low in babies delivered by Caesarean section.

\section{CONCLUSION}

Eclampsia continues to kill our neonates. Proper antenatal care, early recognition of high risk factors and timely management of such cases will help to reduce perinatal mortality.

\section{KEYWORDS}

Eclampsia, Perinatal Mortality, Proteinuria, Uric Acid.

HOW TO CITE THIS ARTICLE: Purandare P, Mishra S, Thakur R, et al. Perinatal outcome in eclampsia- a retrospective study in a tertiary care centre. J. Evolution Med. Dent. Sci. 2017;6(37):3000-3002, DOI: 10.14260/Jemds/2017/647

\section{BACKGROUND}

Eclampsia is an extremely severe form of preeclampsia associated with the sudden onset of tonic-clonic convulsions in a patient with pre-eclampsia. It is a dreaded and potentially life-threatening complication of pregnancy and it continues to be the leading cause of maternal and perinatal morbidity and mortality in both developing and developed countries. Eclampsia accounts for 50,000 maternal deaths every year all over the world and $99 \%$ of these are in developing countries.[1] The incidence of eclampsia has remained constant in developing countries over the last few years.[2] In India too, there has been no reduction in the incidence of eclampsia which has remained constant at $1.5 \%{ }^{[3]}$ Also, though the maternal mortality rate in India has fallen in the last decade, the perinatal mortality has remained high.[3]

Financial or Other, Competing Interest: None.

Submission 15-03-2017, Peer Review 25-04-2017,

Acceptance 01-05-2017, Published 08-05-2017.

Corresponding Author:

Dr. Priyali Purandare,

Adarsh, 503, SAIMS Hospital Campus,

Indore - Saver Road, Indore-452002.

E-mail: priyali_purandare@yahoo.com

DOI: $10.14260 /$ jemds $/ 2017 / 647$
Perinatal mortality is a reflection of the maternal health care services that are being provided to the expectant mothers. This study has been done to find out the perinatal mortality associated with eclampsia in our institute and to study the risk factors leading to a poor perinatal outcome. By doing so, we hope to formulate better treatment protocols in order to improve the perinatal outcome in eclampsia at our hospital.

Improvement in the provision of healthcare services, early detection and timely treatment of such cases can be expected to lead to a reduction in obstetrical and neonatal complications associated with eclampsia.

\section{Aims and Objectives}

1. To determine the perinatal mortality rate associated with eclampsia in our institute.

2. To study the risk factors, which affect perinatal outcome in cases of eclampsia.

\section{MATERIALS AND METHODS}

This is a retrospective observational study carried out at a tertiary care institute. All patients admitted to the labour ward above 28 weeks of gestation with eclampsia between $1^{\text {st }}$ January, 2015 and 31st December, 2015 were included in study. Patients with postpartum eclampsia were excluded from the study. 
The case records of these patients were retrieved from the medical records section and they were analysed in relation to the age of patients, parity, blood pressure, proteinuria and uric acid levels on admission, mode of delivery and perinatal outcome. All data was analysed by descriptive statistical methods using percentages.

\section{RESULTS}

- A total of 61 patients presented with eclampsia in the study period. There were 2 twin deliveries and 1 triplet delivery and so the total number of babies born were 65 .

- Perinatal mortality rate related to eclampsia was $33.8 \%$ (There were 22 perinatal deaths among 65 births).

- Primigravida accounted for 38 out of 61 patients $(62.2 \%)$.

- $\quad 59 \%$ patients (36 out of 61 ) were less than 25 years of age.

- $62 \%$ of the patients (38 out of 61 patients) were unbooked.

- Perinatal deaths was $70.8 \%$ when gestational age was less than 34 weeks and only $12.1 \%$ when gestational age was more than 34 weeks.

\begin{tabular}{|c|c|c|c|}
\hline $\begin{array}{c}\text { Gestational } \\
\text { Age }\end{array}$ & $\begin{array}{c}\text { Total } \\
\text { Number of } \\
\text { Cases }\end{array}$ & $\begin{array}{c}\text { Perinatal } \\
\text { Deaths }\end{array}$ & Percentage \\
\hline$<34$ weeks & 24 & 17 & $70.8 \%$ \\
\hline $\begin{array}{c}\text { and = 34 } \\
\text { weeks }\end{array}$ & 41 & 5 & $12.1 \%$ \\
\hline \multicolumn{3}{|c|}{$\begin{array}{c}\text { Table 1. Relationship of Gestational } \\
\text { Age with Perinatal Mortality }\end{array}$} \\
\hline
\end{tabular}

$95.4 \%$ (21 out of 22 ) perinatal deaths were seen in babies weighing less than $2 \mathrm{~kg}$.

\begin{tabular}{|c|c|c|}
\hline Baby Weight & Perinatal Deaths & Percentage \\
\hline$>$ and = $2 \mathrm{~kg}$ & 1 & $4.5 \%$ \\
\hline$<2 \mathrm{~kg}$ & 21 & $95.4 \%$ \\
\hline \multicolumn{3}{|c|}{ Table 2. Relationship of Birth } \\
Weight with Perinatal Mortality \\
\hline
\end{tabular}

The most common cause of perinatal death was prematurity and low birth weight.

In our study, there was no major difference in perinatal mortality with SBP $>160 \mathrm{mmHg}$ or DBP $>110 \mathrm{mmHg}$.

\begin{tabular}{|c|c|c|c|}
\hline $\begin{array}{c}\text { Systolic BP on } \\
\text { Admission }\end{array}$ & $\begin{array}{c}\text { Total Number } \\
\text { of Patients }\end{array}$ & $\begin{array}{c}\text { Perinatal } \\
\text { Death }\end{array}$ & Percentage \\
\hline $\begin{array}{c}\text { SBP > or equal to } \\
160 \mathrm{mmHg}\end{array}$ & 29 & 11 & $37 \%$ \\
\hline SBP < 160 mmHg & 36 & 11 & $30 \%$ \\
\hline \multicolumn{3}{|c|}{ Table 3. Relationship of Systolic } \\
Blood Pressure with Perinatal Mortality \\
\hline
\end{tabular}

\begin{tabular}{|r|c|c|c|}
\hline $\begin{array}{c}\text { Diastolic BP on } \\
\text { Admission }\end{array}$ & $\begin{array}{c}\text { Total Number } \\
\text { of Patients }\end{array}$ & $\begin{array}{c}\text { Perinatal } \\
\text { Death }\end{array}$ & Percentage \\
\hline $\begin{array}{c}\text { DBP > or equal to } \\
110 \mathrm{mmHg}\end{array}$ & 28 & 10 & $35 \%$ \\
\hline DBP < 110 mmHg & 37 & 12 & $32 \%$ \\
\hline $\begin{array}{r}\text { Table 4. Relationship of Diastolic Blood } \\
\text { Pressure with Perinatal Mortality }\end{array}$ \\
\hline
\end{tabular}

Proteinuria was present in all cases. Perinatal deaths were more with increasing proteinuria.

\begin{tabular}{|c|c|c|c|}
\hline $\begin{array}{c}\text { Urine } \\
\text { Albumin }\end{array}$ & $\begin{array}{c}\text { Total } \\
\text { Patients }\end{array}$ & $\begin{array}{c}\text { Perinatal } \\
\text { Death }\end{array}$ & Percentage \\
\hline $4+$ & 29 & 13 & $44.8 \%$ \\
\hline $3+$ & 17 & 6 & $35.2 \%$ \\
\hline $2+$ & 9 & 2 & $27.2 \%$ \\
\hline $1+$ & 10 & 1 & $10 \%$ \\
\hline \multicolumn{3}{|c|}{$\begin{array}{r}\text { Table 5. Relationship of Proteinuria } \\
\text { with Perinatal Mortality }\end{array}$} \\
\hline
\end{tabular}

Perinatal deaths were more in cases where uric acid levels were $>$ and $=6 \mathrm{mEq} / \mathrm{dL}$.

\begin{tabular}{|c|c|c|c|}
\hline $\begin{array}{c}\text { Uric Acid } \\
\text { (mEq/dL) }\end{array}$ & $\begin{array}{c}\text { Total Number } \\
\text { of Patients }\end{array}$ & $\begin{array}{c}\text { Perinatal } \\
\text { Death }\end{array}$ & Percentage \\
\hline$>$ and equal to 6 & 30 & 13 & $43.3 \%$ \\
\hline$<6$ & 35 & 9 & $25.7 \%$ \\
\hline \multicolumn{2}{|r|}{ Table 6. Relationship of Serum Uric } \\
Acid Levels with Perinatal Mortality \\
\hline
\end{tabular}

Babies delivered by Caesarean had a better perinatal outcome. Only $29 \%$ of babies delivered by Caesarean section died as compared to $41 \%$ of those who were born by normal vaginal delivery.

\begin{tabular}{|c|c|c|c|}
\hline $\begin{array}{c}\text { Mode of } \\
\text { Delivery }\end{array}$ & Total & $\begin{array}{c}\text { Perinatal } \\
\text { Death }\end{array}$ & Percentage \\
\hline $\begin{array}{c}\text { Normal Vaginal } \\
\text { Delivery }\end{array}$ & 24 & 10 & $41 \%$ \\
\hline Caesarean Section & 41 & 12 & $29 \%$ \\
\hline \multicolumn{3}{|c|}{$\begin{array}{c}\text { Table 7. Relationship of Mode } \\
\text { of Delivery with Perinatal Mortality }\end{array}$} \\
\hline
\end{tabular}

\section{DISCUSSION}

Eclampsia is a major contributor to poor perinatal outcome, especially in developing countries like India where maternal services that are being provided are inadequate.

The perinatal mortality rate in cases of eclampsia in our study was found to be $33.8 \%$. In various other studies, perinatal mortality in India has been reported to vary between $24 \%-48 \%{ }^{[3,4,5,6]}$ It is much higher than the perinatal mortality of $5 \%-11 \%$ reported in developed countries.[7]

Majority of the patients in our study was primigravidae $(62.2 \%)$ and most of them were less than 25 years of age (59\%). Both nulliparity and young maternal age has been noted as a risk factor for the development of eclampsia.[8]

$62 \%$ of cases were unbooked. This high percentage of unbooked status was noted in nearly all the Indian studies.[4-6] According to Majhi et al, inadequate antenatal care is closely related to poor perinatal outcome in eclampsia.[9]

Antenatal care is the single most important factor that could help to reduce poor outcome in these cases.[10]

Perinatal mortality was highest when gestational age was less than 34 weeks. This is similar to other Indian studies. ${ }^{[11,4,6]}$ According to Shear et al, gestational age is the strongest predicator of foetal morbidity and mortality.[12]

The incidence of preterm delivery is high in cases of eclampsia as iatrogenic preterm delivery is more common in these cases.[10]

In our study, there was no relation between blood pressure on admission and perinatal mortality. But other 
studies have found maximum perinatal mortality when Blood pressure was more than $160 / 110 \mathrm{mmHg} .[11,5,13]$

Perinatal mortality was highest with urine albumin more than $2+$. Increasing proteinuria has been reported to be associated with higher risk of adverse maternal and foetal outcome.[14]

Uric acid levels $>$ and $=6 \mathrm{mEq} / \mathrm{dL}$ were associated with higher perinatal mortality.

Gopalan $\mathrm{S}^{[15]}$ has reported increased perinatal mortality with uric acid levels $>5.5 \mathrm{mEq} / \mathrm{L}$.

Babies delivered by Caesarean section had a better perinatal outcome. Early caesarean section in eclampsia patients has been favoured to reduce perinatal mortality.[16]

\section{CONCLUSION}

The perinatal mortality in cases of eclampsia in our institute was $33.8 \%$. Perinatal outcome was found to be poor in premature $(<34$ weeks gestation) and low birth weight $(<2$ $\mathrm{kg}$ ) babies born to eclamptic mothers having proteinuria more than $2+$ and uric acid levels $>6 \mathrm{mEq} / \mathrm{L}$. Perinatal mortality was lower in babies delivered by early caesarean section.

Regular antenatal care, early recognition of high risk factors, timely treatment and early intervention in form of operative delivery by LSCS will help to reduce the burden of perinatal mortality. There is an urgent need for obstetricians to aim to improve maternal healthcare services in order to reduce the burden of this dreaded disease named eclampsia.

\section{REFERENCES}

[1] Duley L. The global impact of pre-eclampsia and eclampsia. Semin Perinatol 2009;33(3):130-7.

[2] Dolea C, AbouZahr C. Global burden of hypertensive disorders of pregnancy in the year 2000. Evidence and Information for Policy (EIP). Geneva: World Health Organization 2000.

[3] Nobis PN, Hajong. Eclampsia in India through the decades. J Obstet Gynaecol India 2016;66(Suppl 1):S172-6.

[4] Yaliwal RG, Jaju PB, Vanishree M. Eclampsia and perinatal outcome: a retrospective study in teaching hospital. J of Clinical and Diagnostic Research 2011;5(5):1056-9.
[5] Gaddi SS, Somegowda. Maternal and perinatal outcome in eclampsia in a district hospital. J Obst Gyn Ind. 2007:57(4):324-6.

[6] Ponde SR, Hatkar P, Nandanwar YS, et al. A prospective study of the study of maternal and perinatal outcome in cases of eclampsia. Int J Reprod Contracept Obstet Gynecol 2016;5(10):3433-8.

[7] Knight M. Eclampsia in the United Kingdom 2005. BJOG 2007;114(9):1072-8.

[8] Conde-Agudelo A, Kafury-Goeta AC. Case-control study of risk factors for complicated eclampsia. Obstet Gynecol 1997;90(2):172-5.

[9] Majhi AK, Chakraborty PS, Mukhopadhyay A. Eclampsia - present scenerio in a referral medical college hospital. J Obstet Gynaecol India. 2001;51(3):143-7.

[10] Gupte S, Wagh G. Preeclampsia-eclampsia. J Obstet Gynaecol India 2014;64(1):4-13.

[11] Dhananjay BS, Dayananda G, Sendilkumaran D, et al. A study of factors affecting perinatal mortality in eclampsia. JPBS 2009;22(2):2-5.

[12] Shear RM, Rinfret D, Leduc L. Should we offer expectant management in cases of severe preterm preeclampsia with fetal growth restriction? Am J Obstet Gynecol 2005;192(4):1119-25.

[13] Rajamma CK, Sridevi P. Maternal and perinatal mortality and morbidity in hypertensive disorder complicating pregnancy. Int J Sci Stud 2016;3(11):206-9.

[14] Chan P, Brown M, Simpson JM, et al. Proteinuria in pre-eclampsia: how much matters? BJOG 2005;112(3):280-5.

[15] Mustaphi R, Gopalan S, Dhaliwal L, et al. Hyperuricaemia and pregnancy induced hypertension--reappraisal. Indian J Med Sci 1996;50(3):68-71.

[16] Swain S, Ojha KN, Prakash A, et al. Maternal and perinatal mortality due to eclampsia. Indian Paediat 1993;30(6):771-3. 